\title{
Państwo, demokracja i walka klas. Uwagi na temat udziału socjalistów w debacie konstytucyjnej w sejmie II kadencji (1928-1930)
}

\author{
State, Democracy and Class Struggle. Remarks on Polish Socialists' Participation \\ in the Constitutional Debate (1928-1930)
}

\begin{abstract}
The following article discusses Polish Socialists' participation in the constitutional debate conducted in the Sejm (1928-1930). In the first part, main motives of the criticism formulated by Socialists against constitutional project presented by the Nonpartisan Bloc for Cooperation with the Government (BBWR) are reconstructed. The role played by the constitutional debate in Socialists' tactic is also presented in this section. Subsequently, on the basis of Socialists' statements on constitutional issues, I discuss their class-oriented interpretation of parliamentary democracy. I argue that their perception of the modern state and democracy was coherent with the theory of social change and class struggle established in the Polish socialist thought of that time. I notice roots of this theory in specific "optimist historiosophy", distinctive for the European socialist movement in the 1920s. The beginning of the 1930s started a decline of this optimism and initiated an ideological crisis in the Polish socialist movement.
\end{abstract}

Keywords: democracy, class struggle, socialism, parliamentarism, constitutional law Słowa kluczowe: demokracja, walka klas, socjalizm, parlamentaryzm, prawo konstytucyjne

Badania nad myślą polityczną i dorobkiem programowym najważniejszych obozów politycznych Drugiej Rzeczypospolitej stanowią obecnie bez wątpienia jedną z najdynamiczniej rozwijających się dziedzin rodzimej historiografii dziejów najnowszych. Problematyka ta budzi niesłabnące zainteresowanie zarówno historyków, jak i politologów czy prawników. W rezultacie, kolejne elementy składające się na ideową panoramę międzywojennej Polski, są sukcesywnie opracowywane, a nasza wiedza o debatach politycznych i wielkich sporach programowych Dwudziestolecia z roku na rok ulega znacznemu powiększeniu.

W efekcie trwających już od lat 70. intensywnych badań, dorobek programowy polskiego ruchu socjalistycznego w okresie międzywojennym, uznać należy za 
wszechstronnie opracowany i omówiony w literaturze ${ }^{1}$. Trudno jednak temat ten uznać za już wyczerpany, a obecne w historiografii sądy i konkluzje za niepodważalne. Wciąż istnieje jeszcze sporo „białych plam”, lub też nie dość dokładnie i szczegółowo opracowanych problemów czy tematów. Jednym z nich zdaje się być udział socjalistów w debacie konstytucyjnej toczonej na forum sejmu II kadencji (1928-1930).

Stosunkowo pobieżne potraktowanie tego zagadnienia w istniejącej literaturze może nieco dziwić, zwłaszcza zważywszy, że ustrojowe koncepcje polskich socjalistów budzą od wielu lat szczególne zainteresowanie badaczy, a sam problem rewizji konstytucji przez długie tygodnie 1929 i 1930 roku stanowił jeden z najważniejszych wątków zarówno pepeesowskiej publicystyki, jak i prowadzonej podczas wieców i zebrań agitacji. Wydaje się, że to stosunkowo niewielkie zainteresowanie badaczy wynika z trzech podstawowych powodów. Po pierwsze, debata konstytucyjna w sejmie II kadencji, ze względu na przedterminowe rozwiązanie izb, niejako urwała się w połowie, nie prowadząc do żadnej wyrazistej konkluzji. Co więcej, układ sił w sejmie z góry ograniczał szanse na jakikolwiek kompromis w sprawach ustrojowych, a to znowu skłaniać może do marginalizacji historycznej wagi tej debaty. Po drugie, w wielu ówczesnych wypowiedziach, socjaliści postulowali rozwiązania bardzo podobnych do tych, które sugerowali już podczas prac konstytucyjnych w Sejmie Ustawodawczym, co zdaje się również uzasadniać zdawkowe potraktowanie tego zagadnienia przez badaczy dziejów PPS. Wreszcie, równolegle z debatą konstytucyjną w sejmie II kadencji, toczyła się również ostra walka pomiędzy środowiskami demokratycznej opozycji (z PPS na czele) a obozem pomajowym. Stawką tej walki, jak wiadomo, był dalszy los demokracji parlamentarnej, jej rezultaty zaś w decydujący sposób wpłynęły na ewolucję polskiego systemu politycznego w latach 30. Nie może więc zaskakiwać, że badacze zajmujący się tym okresem, swoją uwagę skupiają właśnie przede wszystkim na analizie kolejnych etapów konfliktu pomiędzy opozycją parlamentarną a obozem pomajowym, znacznie mniej uwagi poświęcając toczonej w tym czasie debacie konstytucyjnej, która - jak się okazało - miała raczej akademicki charakter².

${ }^{1}$ Problematyka ta w sposób szczególnie kompleksowy omówiona została przede wszystkim w pracach S. Michałowskiego i M. Śliwy, zob. S. Michałowski, Myśl polityczna Polskiej Partii Socjalistycznej (1918-1939), Lublin 1994; idem, Polscy socjaliśsi, [w:] Więcej niż niepodlegtość. Polska myśl polityczna 1918-1939, red. J. Jachymek, W. Paruch, Lublin 2001; M. Śliwa, Myśl polityczna Mieczystawa Niedziałkowskiego, Warszawa 1980; idem, Polska myśl socjalistyczna 1918-1948, Wrocław 1988.

2 Przykład takiego ujęcia stanowić mogą dwie klasyczne monografie poświęcone konfliktowi opozycji demokratycznej i obozu pomajowego: St.P. Stęborowski, Geneza Centrolewu 1928-1929, Warszawa 1963; A. Czubiński, Centrolew. Kształtowanie się i rozwój demokratycznej opozycji antysanacyjnej $w$ Polsce $w$ latach 1926-1930, Poznań 1963. 
Uznając wagę tych argumentów, skłonny jestem wyrazić przypuszczenie, że dokładniejsza analiza wybranych aspektów wypowiedzi socjalistów z okresu debaty konstytucyjnej w sejmie II kadencji może prowadzić do obiecujących wniosków i ciekawych interpretacji. Wydaje się, że bliższe przyjrzenie się ówczesnym ustrojowym rozważaniom socjalistów pozwala na wskazanie głównych wątków, prowadzonej wówczas przez nich niezwykle intensywnej krytyki rządów dyktatorskich, a także umożliwia dostrzeżenie wyraźnej wśród nich tendencji do idealizowania demokracji parlamentarnej w jej klasycznym, zachodnioeuropejskim wydaniu. Analiza głosów socjalistów w debacie konstytucyjnej otwiera również szansę zaprezentowania bogactwa i wewnętrznego zróżnicowania argumentacji, którą posługiwali się w walce z obozem pomajowym. Przede wszystkim jednak, dzięki uważnej lekturze ówczesnej publicystyki socjalistów możliwe jest, jak sądzę, uchwycenie istoty formułowanych wówczas przez liderów i ideologów PPS poglądów na nowoczesne państwo w kontekście przenikających społeczeństwo walk klasowych. Wątek ten akcentuję w niniejszym artykule w sposób szczególny, omawiając formułowane przez socjalistów krytyczne oceny projektu konstytucji przedstawionego przez BBWR oraz założenia wysuniętego przez PPS (wspólnie z klubami PSL-Wyzwolenie i Stronnictwa Chłopskiego) projektu nowelizacji ustawy zasadniczej, zwracając uwagę na związek łączący zawarte w publicystyce i sejmowych przemówieniach argumenty z popularnymi wówczas wśród socjalistów wyobrażeniami o dynamice konfliktów klasowych i mechanizmach życia politycznego.

\section{Konstytucja, czyli jak zdemaskować obóz pomajowy}

Wyjątkowe uprawnienia sejmu II kadencji, wybranego w marcu 1928 r., wynikały z zapisów artykułu 125 konstytucji z marca 1921, które przewidywały, że drugi z kolei sejm wybrany na przewidzianych w niej zasadach posiadał będzie prawo do nowelizacji ustawy zasadniczej za pomocą własnej uchwały, podjętej większością 3/5 przy obecności co najmniej połowy ustawowej liczby posłów3. To dość niecodzienne rozwiązanie stanowiło jeden z elementów, zawartego w Sejmie Ustawodawczym, kompromisu konstytucyjnego ${ }^{4}$, w efekcie którego możliwe było pogodzenie sprzecznych dążeń stronnictw prawicowych oraz ugrupowań lewicowych,

3 Stosowny fragment art. 125 ustawy zasadniczej brzmiał: „Drugi z rzędu na zasadzie tej Konstytucji wybrany Sejm może dokonać rewizji Ustawy Konstytucyjnej własną uchwałą, powziętą większością $3 / 5$ głosujących, przy obecności co najmniej połowy ustawowej liczby posłów”, Dz.U. 1921, nr 44, poz. 267.

${ }^{4}$ S. Krukowski, Geneza konstytucji z 17 marca 1921 r., Warszawa 1977, s. 300. 
wśród których w debacie ustrojowej szczególnie aktywni byli właśnie posłowie PPS. Socjaliści liczyli - zgodnie z wpisanym w ich filozofię dziejów progresywizmem - że wyniki kolejnych wyborów przynosić będą wzrost poparcia dla ugrupowań lewicowych, co pozwoli, w oparciu o uproszczoną procedurę nowelizacji konstytucji przewidzianą przez art. 125, dokonać reformy ustroju zbieżnej z postulatami wysuniętymi przez lewicę w latach 1918-1921.

Po upływie siedmiu lat od uchwalenia konstytucji marcowej, sytuacja na polskiej scenie politycznej, przede wszystkim w wyniku zamachu majowego, uległa jednak poważnej zmianie. Dla wielu obserwatorów jasnym było, że głównym zadaniem ugrupowań lewicowych w sejmie II kadencji, z liczącym 64 posłów klubem PPS na czele , będzie raczej obrona istniejącego porządku ustrojowego, niż jego zmiana. Postulat nowelizacji konstytucji stanowił za to jedno z najważniejszych haseł w repertuarze agitatorów BBWR, jednak reforma ta miała iść w kierunku przeciwnym względem oczekiwań socjalistów ${ }^{6}$.

Mimo wyraźnego dążenia liderów obozu pomajowego do konstytucyjnego usankcjonowania rządów autorytarnych i iluzorycznych szans na znalezienie większości dla postulatów ustrojowych PPS, socjaliści byli zwolennikami podjęcia przez sejm prac nad nowelizacją ustawy zasadniczej. St.P. Stęborowski w studium, które zaliczyć można dziś już do klasyki historiografii dziejów politycznych Drugiej Rzeczypospolitej, jednoznacznie ocenia zgodę wyrażoną przez opozycję demokratyczną na wszczęcie procedury rewizji konstytucji jako błąd polityczny i wyjście naprzeciw oczekiwaniom obozu pomajowego7. Wydaje się jednak, że ocena ta jest nie do końca sprawiedliwa i wynika raczej z koncentracji na długofalowych skutkach polityki socjalistów z lat 1928-1929, niż z refleksji nad przesłankami decyzji przywódców PPS.

Przyczyny postępowania socjalistów można byłoby podzielić na "taktyczne” $\mathrm{i}$,strategiczne”. W tym pierwszym wypadku chodziło o potrzeby narzucane przez bieżącą agitację polityczną. Rezygnacja ze skorzystania z uproszczonej procedury zmiany konstytucji, której wprowadzenie do ustawy zasadniczej socjaliści od lat prezentowali jako swój sukces, mogłaby być niezrozumiała dla sporej części sym-

\footnotetext{
5 J. Tomicki, Polska Partia Socjalistyczna 1892-1948, Warszawa 1983, s. 296, 302.

${ }^{6}$ St.P. Stęborowski, op. cit., s. 80-81.

7 „Pozostaje faktem - pisze Stęborowski - że lewica sejmowa wyrażając zgodę na przystąpienie przez Sejm do rewizji Konstytucji marcowej umożliwiła BBWR zmianę Konstytucji w duchu antydemokratycznym. [...] Co więcej, lewica sejmowa przyczyniła się nie do obrony istniejącego porządku prawnego, lecz do jego burzenia, bowiem przyjmując wniosek w sprawie rewizji Konstytucji uznała jej nieprzydatność dla aktualnych potrzeb życia państwowego w warunkach rozwijanej przez sanację ofensywy politycznej”, ibidem, s. 190.
} 
patyków partii. Herman Lieberman podczas debaty w sprawie podjęcia prac konstytucyjnych przez sejm II kadencji pośrednio przyznawał to, mówiąc, że ,jeżeli lewica wywalczyła w pierwszym Sejmie prawo rewizji, to gdy nadarza się sposobność i konieczność skorzystania z tego prawa, przed tym zadaniem nie powinna uciekać"s.

Jednocześnie, nie uchylając się od dyskusji nad rewizją konstytucji, socjaliści wytrącali z rąk przywódców obozu pomajowego wygodny argument, mówiący o tym, że stronnictwa opozycyjne, rzekomo w imię obrony poselskich przywilejów, uniemożliwiają prace nad „naprawą ustroju”. Jak wiadomo, zwolennicy rządów pomajowych bardzo chętnie zarzucali opozycji niezdolność do konstruktywnej pracy na rzecz państwa, przypuszczać można więc, że odrzucenie wniosku o rozpoczęcie prac nad rewizją konstytucji oznaczałoby początek kolejnej forsownej kampanii agitacyjnej obliczonej na kompromitowanie sejmu w oczach opinii publicznej. Na to zaś, w kontekście narastającego konfliktu między opozycją demokratyczną a rządami pomajowymi, socjaliści nie mogli pozwolić. Co więcej, żywili nadzieję, że możliwe będzie wykorzystanie debaty konstytucyjnej do obnażenia rzeczywistego oblicza klasowego rządów pomajowych.

Względy „strategiczne”, jakie mieli socjaliści na uwadze, godząc się na wszczęcie procedury nowelizacji konstytucji wiązały się bezpośrednio z, szeroko rozpowszechnioną wśród nich, koncepcją zasad rządzących dynamiką życia politycznego. Socjaliści byli przekonani, że powinna istnieć ścisła zależność pomiędzy miejscem zajmowanym przez jednostkę w strukturze klasowej społeczeństwa, a jej politycznymi wyborami. Innymi słowy, w sytuacji modelowej, robotnicy winni popierać partie socjalistyczne, jako reprezentujące ich klasowy interes, zaś kapitaliści czy właściciele ziemscy swoje sympatie lokować powinni po prawej stronie sceny politycznej. Różnice zachodzące między takim modelem a rzeczywistą sytuacją, socjaliści tłumaczyli zwykle niskim poziomem politycznego uświadomienia lub dezorientacją wynikłą na przykład z niejasności co do rzeczywistych zamiarów przywódców stronnictw politycznych. Tutaj też znajdować miało się, zdaniem socjalistów, źródło wciąż jeszcze sporego poparcia społecznego dla obozu pomajowego, reprezentującego wszak, w ich ocenie, „obiektywnie” klasy posiadające. Przywódcy socjalistów liczyli, że właśnie dzięki debacie konstytucyjnej, podczas której trudno będzie poprzestać na niewiele znaczących i poddających się wielostronnej interpretacji ogólnikach, łatwiejsze stanie się zdemaskowanie, w oczach opinii publicznej, rzeczywistego oblicza klasowego rządów pomajowych, co znakomicie

${ }^{8}$ Sprawozdania Stenograficzne z posiedzeń Sejmu (dalej: SSS), pos. 38 z dn. 15.01.1929, 1. 26-27. 
mogłoby przyczynić się w rezultacie do ich delegitymizacji i przyspieszenia powrotu do demokracji parlamentarnej?.

Silne były również wśród socjalistów nadzieje na to, że w toku debaty konstytucyjnej dadzą o sobie znać tendencje odśrodkowe w obozie pomajowym. Mieczysław Niedziałkowski ironicznie opisywał dążenia przedstawicieli różnych części składowych obozu: „Przedświt” uczynił z „etatyzmu” swój kamień węgielny. [...] Grupa „liberalno-postępowa” pp. Kościałkowskiego i Lechnickiego chciałaby „demokracji z poprawkami”. Cały kłopot - z ustaleniem tych „poprawek”. P. Wałek-Czarnecki widzi zbawienie w „systemie prezydenckim”; ktoś inny w ucieczce od „etatyzmu”; ktoś trzeci w „syndykalizmie”; p. prof. Bartel w „systemie kanclerskim”. A z jeszcze innej strony pada gromkie hasło starożytnych Rzymian: „cezar i lud”. [...] Konserwatyści, którzy „witają radośnie” wszelkie „konflikty” między Sejmem a Rządem, wygodniejszą mają sytuację: niech przyjdzie kryzys państwowy; niech wybuchnie walka; Piłsudski wygra a po nim przybędzie „k ról oczekiwany a nieznany” [...]. Tuż obok prof. Wł.L. Jaworski buduje „polskie państwo korporacyjne” w imię „moralności Chrystusowej”"

Początkowo socjaliści nie wierzyli, że BBWR będzie zdolny do tego, aby przedstawić jeden, akceptowany przez wszystkie grupy i środowiska wchodzące w jego skład, projekt konstytucji. Stąd miało się brać więc niezdecydowanie widoczne, zdaniem socjalistów, w szeregach obozu rządowego i dążenie do tego, aby zablokować debatę konstytucyjną przy jednoczesnym obarczeniu odpowiedzialnością za to opozycji. Podczas debaty sejmowej w styczniu 1929 Adam Pragier wyjaśniał: „My rozumiemy dobrze to położenie i wiemy, że ta gromada ludzi, zebranych razem pod mianem Bezpartyjnego Bloku, nie może stworzyć programu konstytucyjnego i dlatego chce, aby ją od tego w taki lub owaki sposób uwolnić" ${ }^{11}$.

${ }^{9}$ M. Niedziałkowski wyjaśniając taktykę socjalistów w sejmie II kadencji pisał: „Chorągwią ideową obozu „sanacyjnego” było hasło „naprawy” Konstytucji. W latach 1926, 1927 i 1928 hasło to formułowano z tamtej strony wyłącznie negatywnie: zwalczano gwałtownie Konstytucję z dn. 17-go marca 1921 r., nie mówiono, jaki plan przebudowy ustroju Państwa jej się przeciwstawia. Chcieliśmy, ażeby Blok Bezpartyjny wystąpił z takim planem konkretnym. Gdyby szukanie „rozgrywki” poprzednio przy jakiejkolwiek sposobności stało się - na wzór narodowej demokracji - i naszą polityką - „rozgrywka” sama utonęłaby we mgle pustych ogólnikowych frazesów. Klub BB zgłosił swój projekt konstytucji. I w masach nastąpił gwałtowny, żywiołowy odruch protestu. Uwypukliły się zarazem jaskrawo istotne tendencje „pomajowego” systemu rządzenia”, M. Niedziałkowski, Polityka demokracji, Robotnik, 5.09.1929, s. 1 .

${ }^{10}$ Idem, Ślepy zautek, Robotnik, 26.01.1929, s. 1.

11 SSS, pos. $39 \mathrm{z} \mathrm{dn.} \mathrm{22.01.1929,} \mathrm{ł.} 41$. 


\section{Państwo biurokratów i kapitału}

Ostatecznie jednak, wbrew oczekiwaniom socjalistów, 6 lutego 1929 Walery Sławek w imieniu BBWR złożył do laski marszałkowskiej projekt nowelizacji konstytucji ${ }^{12}$, a rozważania o przenikającym go duchu, głównych zasadach, na których został oparty, a także o poprawności użytych sformułowań i szczegółowych rozwiązaniach proponowanych przez jego autorów, na długie tygodnie zapełniły szpalty socjalistycznych pism i teksty przemówień wygłaszanych na organizowanych przez PPS wiecach czy zgromadzeniach. Pierwszą całościową ocenę projektu złożonego przez BBWR dał M.Niedziałkowski, uchodzący za najwybitniejszego znawcę materii konstytucyjnej w szeregach PPS. W opublikowanym już dwa dni później (8 lutego) w „Robotniku” artykule, zatytułowanym Program konstytucyjny B.B. dowodzil, że wcielenie w życie projektu reformy ustrojowej przedstawionego przez BBWR, oznaczałoby „sztuczne” wzmocnienie wpływu, wywieranego na państwo przez klasy posiadające. Jego zdaniem, projekt BBWR przewidywał przesunięcie władzy w ręce wyższej biurokracji cywilnej i wojskowej, stanowiącej, zdaniem socjalistów, jeden z filarów obozu pomajowego. Recenzowany projekt był, w jego ocenie, zdecydowanie konserwatywny; redaktor „Robotnika” widział w nim próbę zatrzymania, albo wręcz cofnięcia, dokonujących się po wojnie procesów demokratyzacji życia społecznego i politycznej emancypacji klas pracujących. Podsumowując swoje rozważania, pisał: „Sztuczny przerost wpływu na Państwo kapitału, ziemiaństwa i biurokracji, przy sztucznym zmniejszeniu wpływu klasy robotniczej i włościaństwa oznacza niemożność spokojnego rozwoju Polski do nowych społeczno-gospodarczych i kulturalnych form jej istnienia, a tym samym niemożność utrwalenia Niepodległości”'13.

Artykuł Niedziałkowskiego w zasadzie wyznaczył główne kierunki, formułowanej w kolejnych miesiącach przez socjalistów, krytyki ustrojowych koncepcji obozu pomajowego. Zarówno w wystąpieniach na forum sejmowym, jak i prasowych artykułach, podkreślano, że BBWR dąży do wzmocnienia pozycji klas posiadających, odrzucając jednocześnie całą tradycję zachodnioeuropejskiego liberalnego konstytucjonalizmu. Szczególnie mocno krytykowano dążenie projektu BBWR do podważenia zasady politycznej suwerenności narodu. W słowach: „Źródłem władzy w Rzeczypospolitej Polskiej jest Naród [...]”, otwierających projekt BBWR, publicyści i parlamentarzyści PPS skłonni byli widzieć jedynie pró-

${ }^{12}$ Zob. M. Wojtacki, Wstęp, [w:] Prace Komisji Konstytucyjnej Sejmu Rzeczypospolitej Polskiej II kadencji (1928-1930), oprac. M. Wojtacki, Warszawa 2013, s. 21.

${ }^{13}$ M. Niedziałkowski, „Program konstytucyjny” B.B., Robotnik, 8.02.1929, s. 1. 
bę stworzenia pozorów demokratyzmu, nie zaś zasadę stanowiącą faktyczny fundament całej konstrukcji ustrojowej. Wskazywał na to Herman Lieberman podczas jednego z posiedzeń Komisji Konstytucyjnej: „Proszę popatrzeć: po pierwsze, wszystko zaczyna się metafizyką. Źródtem władzy Rzeczypospolitej jest naród, Prawem naczelnym jest dobro Państwa. Już to budzi wątpliwości, bo jak się tak w partykułach, w rozmowach mówi o tym superema lex salus rei publice, to to ślicznie wygląda, ale w ustawie w związku z innymi przepisami to budzi olbrzymie wątpliwości. I zaraz panom pokażę: już w drugim artykule rzucona jest smuga światła na to, co to znaczy ta metafizyka, polegająca na przyznaniu narodowi źródła władzy. Najwyższym przedstawicielem władzy państwa w Polsce jest Prezydent Rzeczypospolitej. Wszelkiej władzy. Już nie ma tych granic, jakie są w konstytucji obowiązujące. Naczelną władzą, organem narodu w zakresie tej władzy i rządu - to już przedstawiciel władzy bez różnicy, prezydent, jednostka. W połączeniu z naczelnym prawem - dobro państwa - daje to doktrynę tyranii jednostki"14.

$\mathrm{Na}$ ten sam problem zwracał uwagę również Adam Próchnik, często poruszający wówczas problematykę konstytucyjną ${ }^{15}$. Próchnik dowodził, że przewidywane przez projekt obozu rządowego, powszechne wybory głowy państwa, mającej zająć centralną pozycję w całej konstrukcji ustrojowej, nie czynią wcale zadość zasadzie suwerenności politycznej narodu i tradycjom zachodniego demokratyzmu. O tym, że powszechny plebiscyt stać się może wygodnym narzędziem w rękach demagogicznego przywódcy świadczył, jego zdaniem, przykład Napoleona III, który miał w zwyczaju w ten sposób legitymizować swoją władzę. Jak pisał Próchnik: „Mawiał chętnie, że chce zostać ochrzczony wodą głosowania powszechnego, ale nie chce żyć trzymając nogi w tej wodzie. A więc Napoleon III dawał wyraz temu kierunkowi, który chce związek z narodem ograniczyć tylko do jednej chwili, to jest do chwili wyboru prezydenta”. Dalej publicysta zauważał, już odnosząc się w sposób bezpośredni do projektu BBWR: „Po tej chwili ten związek zupełnie

${ }^{14}$ Prace Komisji Konstytucyjnej..., s. 246; wystąpienie to zostało przedrukowane również w „Robotniku” choć w wersji nieco innej niż ta opublikowana w cytowanym wydawnictwie źródłowym, por. Faszyzm jako podstawa dyktatorskiej konstytucji zaprojektowanej przez Klub BB, Robotnik, 29.01.1930, s. 3.

15 Próchnik, obok m.in. M. Niedziałkowskiego, H. Libermana i K. Czapińskiego, zasiadał jako przedstawiciel PPS w Komisji Konstytucyjnej. W toku debaty konstytucyjnej opublikował na łamach „Robotnika” szereg obszernych artykułów poświęconych problematyce ustrojowej, szczególnie wiele uwagi poświęcając historycznym źródłom koncepcji głoszonych przez przedstawicieli BBWR, zob. A. Próchnik, Czy demokracja parlamentarna?, Robotnik, 19.02.1929, s. 3; idem, Utrwalenie w konstytucji walki rzadu z sejmem, Robotnik, 10.03.1929, s. 2; idem, Bez kontroli, Robotnik, 18.06.1929, s. 3; idem, Fatszywa ocena, Robotnik, 12.10.1929, s. 1; idem, „Człowiek opatrznościowy", Robotnik, 15.02.1930, s. 3. 
się zrywa, a władza raz powierzona prezydentowi pozostaje potem bez poważniejszego wpływu ze strony społeczeństwa" ${ }^{16}$. W sytuacji, gdy społeczeństwo dokonywać miałoby wyboru jedynie między dwoma, odgórnie wskazanymi, kandydatami, słowa projektu BBWR, głoszące, że to naród stanowi źródło władzy w państwie, okazywały się, zdaniem socjalistów, jedynie nic nie znaczącym frazesem.

Przewidywane przez projekt obozu rządowego radykalne ograniczenie kontroli społecznej nad władzą i wpływu obywateli na wybór osób sprawujących najwyższe urzędy, rodzić miało, zdaniem socjalistów, ryzyko poważnego zaostrzenia konfliktów klasowych. Jak dowodzili publicyści PPS, pozbawione możliwości legalnej walki o realizację własnych interesów (poprzez zdobycie wpływu na instytucje państwowe), klasy pracujące mogły szybko okazać się skłonne do poszukiwania dróg walki o poprawę własnego losu w gwałtownych, podważających istniejący ład, wystąpieniach. Warto podkreślić, że groźba rewolucji, wzrostu tendencji skrajnych i ciągłych niepokojów wewnętrznych powracała bardzo często w podejmowanych przez socjalistów próbach wyobrażenia sobie sytuacji Polski po zrealizowaniu reformy ustrojowej zgodnej z postulatami BBW ${ }^{17}$.

Pośród najważniejszych zarzutów wysuwanych przez socjalistów pod adresem ustrojowych koncepcji BBWR wymieć należałoby jeszcze przestrogi przed pogorszeniem pozycji Polski na arenie międzynarodowej i przed osłabieniem sił obronnych państwa, a także ostrzeżenia przed możliwym paraliżem państwa, wynikłym, ich zdaniem, z prób rozwiązania na poziomie ustawy zasadniczej narastającego konfliktu między opozycją parlamentarną a rządem ${ }^{18}$.

16 Prace Komisji Konstytucyjnej..., s. 321.

17 Najlepszy przykład tego typu rozważań stanowić może niepodpisany, dwuczęściowy artykuł opublikowany w „Naprzodzie” pod tytułem A gdy projekt posła Stawka stał się prawem..., którego autor szkicuje krajobraz polityczny w Polsce po, hipotetycznym, uchwaleniu nowej konstytucji w oparciu o projekt BBWR. Opowieść tę kończy prezentacja przebiegu wyborów prezydenckich, w których udział wzięło (zgodnie z postulatami BBWR) dwóch kandydatów - jeden wskazany przez ustępującego prezydenta, drugi zaś przez Zgromadzenie Narodowe. „Pierwszy był wybitnym wojskowym” - pisano w „Naprzodzie” - „drugi uczonym o europejskiej sławie. Pierwszy pochodził z Krakowa, drugi z Wilna. Poza tym ich oblicze polityczne było identyczne, jak u rodzonych braci. Właściwie wyborcy nie mieli po co stawać do wyborów, było im wszystko jedno, kto zwycięży w tej pozornej walce... Wkrótce nowowybrany prezydent - w zgodzie z konstytucją - złożył przysięgę w katedrze na Wawelu. Tu i ówdzie zaczęły się zamieszki... Nad krajem wschodziła łuna przewrotu”, zob. A gdy projekt posta Stawka stat się prawem..., Naprzód, 2.03.1929, s. 4.

18 Zob. J.M.B. [J.M. Borski], Projekt konstytucji BB w oświetleniu jego twórców, Naprzód, 24.02.1929, s. 4; A. Próchnik, Utrwalenie w konstytucji walki rządu z sejmem, Robotnik, 10.03.1929, s. 2. 


\section{Sposoby argumentacji}

Rezygnując z pobieżnego choćby omówienia wszystkich krytycznych opinii i argumentów pojawiających się w wypowiedziach socjalistów na temat projektu konstytucji złożonego przez BBWR, chciałbym zwrócić tutaj uwagę na fakt, że pepeesowscy mówcy i publicyści odwoływali się do bardzo różnych, często odległych od siebie stanowisk ideowych i układów wartości. Z jednej strony, sięgano oczywiście do argumentacji bezpośrednio wynikającej z teoretycznych założeń socjalizmu, takich, jak choćby przekonanie o tym, że antagonizmy klasowe są siłą poruszającą naprzód koła historii. Odwołania do marksistowskiego uniwersum pojęciowego były niezwykle częste zwłaszcza wówczas, gdy socjaliści próbowali dokonać ogólnej oceny „obiektywnej” funkcji, jaką odegrałby projekt BBWR, gdyby został wcielony w życie lub jakie byłyby jego konsekwencje dla dalszego przebiegu walk klasowych. Autorem szczególnie często sięgającym po język analizy klasowej był przede wszystkim M. Niedziałkowski ${ }^{19}$.

Równolegle, z niemniejszą częstotliwością, socjaliści sięgali po argumentację zaczerpniętą z tradycji liberalnej, a więc odwołującą się do innego układu wartości, niż te, na których oparta jest, klasowo zorientowana, analiza marksistowska. Socjaliści wskazywali choćby, że projekt BBWR znacząco ogranicza możliwości kontroli społeczeństwa nad władzą, a zwłaszcza kontroli nad wysokością podatków i sposobem wydatkowania publicznego grosza ${ }^{20}$. Bezpośrednio do tradycji liberalnego konstytucjonalizmu odnoszono się również krytykując odrzucenie przez twórców projektu BBWR klasycznego trójpodziału władz, pogwałcenie zasady politycznej suwerenności narodu czy podporządkowanie praw i wolności jednostki, arbitralnie wyznaczanemu przez władze „interesowi państwa”. W tym duchu zwykle utrzymane były wywody $\mathrm{H}$. Liebermana, sporej części anonimowych publicystów prowincjonalnych pism PPS, a poniekąd również analizy A. Próchnika.

Krytykując fetyszyzowanie odgórnie definiowanego „interesu państwa” w projekcie BBWR, socjaliści sami chętnie sięgali po argumenty typowo „państwowe”, dowodząc, że realizacja postulatów ustrojowych obozu rządowego godzi właśnie w ... interes państwa, podważając wręcz fundamenty jego niepodległości. Wszystkie niemal wypowiedzi socjalistów z okresu debaty konstytucyjnej podnoszą problem zapewnienia stabilności wewnętrznej, sposobów umacniania niepodległości czy wzmocnienia w szerokich masach społecznych poczucia odpowiedzialności za

19 Zob. M. Niedziałkowski, „Program konstytucyjny” BB, Robotnik, 8.02.1929, s. 1; idem, Podobieństwa i różnice, Robotnik, 19.03.1929, s. 1.

20 Zob. Czego chca oni?, „Dziennik Ludowy, 20.11.1929, s. 2; H. Lieberman, Przelicytowany faszyzm, Naprzód, 4.12.1929, s. 2; A. Próchnik, Bez kontroli, Robotnik, 18.06.1929, s. 3. 
państwo i związków z nim. Jak starał się będę dalej dowieść, niezwykle silne eksponowanie takiej „państwowej” argumentacji wynikało wprost z przyjmowanych przez socjalistów założeń teoretycznych.

Rozważając sposób konstruowania argumentacji socjalistów w sporze z twórcami projektu konstytucyjnego BBWR, zwrócić należy uwagę na to, że ważny punkt odniesienia stanowiły również kryteria technicznej doskonałości używanych sformułowań i zasady redakcji aktów prawnych. Przyjmując pozę (nie zawsze udanie) bezstronnych recenzentów projektu BBWR, socjaliści zwracali uwagę na nieprecyzyjne sformułowania czy sprzeczności zachodzące zarówno pomiędzy poszczególnymi przepisami, jak i pomiędzy deklarowanymi intencjami twórców a rzeczywistymi skutkami, jakie nieść miałoby za sobą wcielenie w życie sugerowanych przez nich rozwiązań. Często proponowane przez BBWR zapisy starano się wręcz sprowadzić ad absurdum - tak było choćby z postulowanym podniesieniem granicy wieku wyborczego ${ }^{21}$, poszerzeniem możliwości wydawania przez prezydenta dekretów z mocą ustawy przy jednoczesnym utrzymaniu Senatu ${ }^{22}$, czy wreszcie z uzależnieniem uchwalenia votum nieufności urzędującemu gabinetowi od zdobycia przez wnioskodawców poparcia większości bezwzględnejej ${ }^{23}$ Każdorazowo, jak wskazywali socjaliści, rozwiązania proponowane przez BBWR miały w praktyce przynosić skutki dokładnie odwrotne od zamierzonych, co dowodzić miało słabej znajomości problematyki konstytucyjnej i nieumiejętności uzgodnienia wysuwanych postulatów z pragmatyką nowoczesnego ustawodawstwa.

Stosowanie tak zróżnicowanej argumentacji bez wątpienia pomagało socjalistom wychodzić nieraz w sposób zwycięski z oratorskich pojedynków, toczonych z mówcami reprezentującymi obóz pomajowy podczas posiedzeń Komisji Konstytucyjnej czy plenarnych sesji sejmu. Jednocześnie, pozwalało na przeprowadzenie wielostronnej krytyki projektu przedstawionego przez BBWR, która, analizowana dzisiaj, wystawia stosunkowo dobre świadectwo socjalistom jako znawcom materii konstytucyjnej i zasad nowoczesnego prawodawstwa. Wydaje się jednak, że odwoływanie się do tak różnych wartości i sposobów argumentacji, mogło czynić przekaz socjalistów niejednolitym i trudno zrozumiałym dla części potencjalnych sympatyków. Można było odnieść wrażenie, że socjaliści jednocześnie chcą być obrońcami tradycyjnego konstytucjonalizmu liberalnego, a zarazem dążą do tego, aby być orędownikami radykalnej „demokracji ludowej”, przyznającej decydujący wpływ na państwo, przedstawicielom klas pracujących. Jednocześnie podkreślali,

${ }^{21}$ Na drodze do bonapartyzmu (II), Dziennik Ludowy, 14.02.1929, s. 1; J.M.B. [J.M. Borski], Projekt konstytucji BB w oświetleniu jego twórców, Naprzód, 24.02.1929, s. 4.

${ }^{22}$ Zob. Prace Komisji Konstytucyjnej..., s. 326.

${ }^{23}$ Ibidem, s. 180. 
że projekt BBWR należy odrzucić przede wszystkim ze względu na fundamentalne zasady, które legły u jego podstaw, z drugiej jednak strony, wielokrotnie wikłali się w szczegółowe analizy pojedynczych przepisów i techniczną ocenę jakości użytych sformułowań, tracąc na chwilę z pola widzenia najważniejsze założenia projektu. Zarazem mówili o walce klasowej jako podstawowym fakcie społecznym i gwarancji rychłego zniesienia kapitalizmu, przyznając jednocześnie, że należy szukać takich rozwiązań ustrojowych, które pozwolą łagodzić antagonizmy klasowe, zabezpieczając tym samym stabilizację sytuacji wewnętrznej państwa. Wydaje się więc, że wykorzystywanie tak różnorodnych argumentów mogło czynić przekaz socjalistów zbyt rozproszonym i trudnym, dla sporej części ich politycznej klienteli, nie rekrutującej się przecież w większości spośród osób dobrze wykształconych i biegłych w abstrakcyjnych rozważaniach prawniczych.

\section{Walka klasowa a ewolucja ustrojów państw powojennych}

Jak wspomniałem na wstępie, debata konstytucyjna przeprowadzona w sejmie II kadencji, w okresie narastania konfliktu między opozycją parlamentarną a, dążącym coraz wyraźniej do ustanowienia systemu autorytarnego, obozem pomajowym, stanowiła dla socjalistów znakomitą inspirację i pretekst do wszechstronnej krytyki rządów dyktatorskich. W tym okresie, socjaliści opisywali już pomajowy „system rządzenia” jako dyktaturę, choć niejednokrotnie mieli problemy z określeniem, czy jest ona ,jawna” czy „ukryta” ${ }^{24}$ oraz kto miałby stanowić jej zasadniczy podmiot (biurokracja? klasy posiadające? wojskowa koteria?). Projekt reformy ustrojowej przedstawiony przez BBWR traktowano więc jako wyraz dążenia do zalegalizowania stosowanej od zamachu praktyki sprawowania władzy oraz próbę stworzenia konstytucyjnej gwarancji stabilności i ciągłości dla rządów pomajowych, niezależnie od poziomu społecznego poparcia ${ }^{25}$.

${ }^{24}$ Częściej publicyści PPS używali sformułowania „ukryta dyktatura”, które wskazywać miało na fakt zachowania pozorów parlamentaryzmu i dalszego obowiązywania konstytucji pomimo dyktatorskich metod sprawowania rządów. Ponadto, mówiąc o „ukrytej dyktaturze” socjaliści wskazywali na fakt, że faktyczny ośrodek decyzji politycznych (J. Piłsudski i jego najbliższe otoczenie) znajduje się w innym miejscu, niż mogłoby wynikać zarówno z hierarchii urzędów państwowych, jak i pewnych pozornych gestów wykonywanych przez polityków obozu pomajowego. „Jawną dyktaturę” socjaliści w omawianym okresie kojarzyli raczej z otwartym użyciem przemocy przeciwko opozycji (lub groźbą takiego postępowania) oraz utożsamieniem formalnych i nieformalnych ośrodków władzy. Stąd też zapowiedzi ustanowienia ,jawnej dyktatury” pojawiały się w ich wypowiedziach choćby po objęciu stanowiska premiera przez Piłsudskiego w sierpniu 1930 r. czy też po aresztowaniach brzeskich.

${ }_{25}$ Zob. Ciężkie chmury nad Polską, Dziennik Ludowy, 25.02.1929, s. 1. 
Podejmując krytykę dyktatury, socjaliści dowodzili, że w nowoczesnym państwie, w warunkach rozwiniętej gospodarki kapitalistycznej, rządy jednostki w istocie są niemożliwością, a nazwisko charyzmatycznego przywódcy stanowi jedynie parawan, za którym kryje się władza klas posiadających oraz wyższej biurokracji. Polemizując z autorami projektu konstytucji BBWR, Mieczysław Niedziałkowski mówił: „Pełni władzy, tak olbrzymiej, jaką chcecie dać Prezydentowi Rzeczypospolitej, nigdy nie będzie, bo nigdy w historii nie było pełni władzy jednego człowieka. W XX stuleciu, w dzisiejszym okresie rozwoju gospodarczego, społecznego i kulturalnego, jeden człowiek, chociażby się nazywał Mussolinim, Primo de Riverą, Piłsudskim, chociażby się nazywał samowładnym monarchą - wszystko jedno - takiej pełni władzy jeden człowiek w swoich rękach nigdy skupić nie potrafi, bo zbyt powiększone, zbyt skomplikowane i zbyt trudne są wszystkie zagadnienia stojące przed państwem. Im większa władza prezydenta, tym większa władza biurokracji" 26 .

Podobnych wypowiedzi można byłoby przytoczyć znacznie więcej; socjaliści myśl o koncentracji władzy w rękach jednostki uważali za absurd, dowód braku politycznej wyobraźni jej orędowników albo też sprytny zabieg, obliczony na ukrycie przed społeczeństwem klasowego charakteru rządów dyktatorskich.

W powojennych dyktaturach, tak licznie rozmnożonych w Europie, socjaliści widzieli ostatnią, rozpaczliwą, ale i brutalną próbę ratowania dominującej pozycji klas posiadających. Demokracja parlamentarna, jak dowodzili, stała się po wojnie narzędziem za pomocą którego dokonywać miała się stopniowa emancypacja klas pracujących ${ }^{27}$. Nic dziwnego więc, że bardzo szybko parlamentaryzm uczyniono przedmiotem najostrzejszych ataków ze strony, zagrożonych utratą przywilejów i władzy, kapitalistów, finansjery i wielkich posiadaczy ziemskich. M. Niedziałkowski, który spośród publicystów PPS w sposób najbardziej pogłębiony analizował społeczne przesłanki systemów dyktatorskich ówczesnej Europy, pisał, że „wszystkie razem i wszystkie z osobna stanowią odbicie niejako tego samego ruchu, tego samego wysiłku świata kapitalistycznego, by zatrzymać pochód Świata Pracy, by sztucznie zahamować pędzące naprzód koła Historii”"28.

Wyraz podobnych prób zatrzymania, procesu dziejowego, prowadzącego, zdaniem publicystów i przywódców PPS, w naturalny sposób do ustanowienia socja-

26 SSS, pos. 52 z dn. 22.02.1929, ł. 20.

27 Zob. J.M.B. [J.M. Borski], Drogi dyktatury, Robotnik, 17.01.1929, s. 1; idem, Dyktator i dyktatura, Dziennik Ludowy, 7.02.1929, s. 2; M. Porczak, Na Święto Proletariatu, Dziennik Ludowy, 2.05.1929, s. 2; idem, Piętnasta rocznica, Dziennik Ludowy, 5.08.1929, s. 2; H. Diamand, Bezpartyjność a demokracja, Robotnik, 12.06.1929, s. 3.

${ }^{28}$ M. Niedziałkowski, Wóz albo przewóz, Robotnik, 26.11.1929, s. 1. 
lizmu, stanowić miał również projekt konstytucji przedstawiony przez BBWR. Tym dążeniom, socjaliści przeciwstawiali demokrację parlamentarną, w której widzieli ustrój najbardziej elastyczny, czuły na najmniejsze przesunięcia w układzie sił klasowych i łatwo się do nich dostosowujący. Warto zauważyć, że przejawiali przy tym wyraźną skłonność do wyolbrzymiania zalet demokracji, a w interesującym nas tutaj okresie niejednokrotnie w dość naiwny sposób idealizowali stosunki panujące we wzorowych, ich zdaniem, demokracjach zachodnich, czyli we Francji i Wielkiej Brytanii ${ }^{29}$.

Socjaliści wysuwali wiele argumentów mających świadczyć o wyższości systemów demokratycznych nad rządami dyktatorskim, związanych głównie z problemem społecznej kontroli nad poczynaniami władz ${ }^{30}$, ideowym charakterem konfliktów politycznych (w przeciwieństwie do zakulisowych personalnych rozgrywek cechujących dyktatury ${ }^{31}$ ) czy silniejszym poczuciem przywiązania obywateli do państwa. Oś argumentacji socjalistów stanowiło oczywiście twierdzenie, że w systemach demokratycznych społeczeństwo samo decyduje o obsadzie najwyższych urzędów. Warto jednak zauważyć, że raczej nie odwoływano się przy tym do, w gruncie rzeczy liberalnej, argumentacji głoszącej, że społeczeństwo może podlegać tylko tej władzy, na której istnienie wyraziło zgodę. Swoje poparcie dla demokracji parlamentarnej socjaliści starali się uzasadnić przede wszystkim na płaszczyźnie klasowej, wobec czego koniecznym było stworzenie spójnej koncepcji łączącej analizę dynamiki konfliktów klasowych z procesem kształtowania się sympatii politycznych społeczeństwa i rezultatami walki wyborczej. Explicite koncepcja ta wyłożona została przez socjalistów właśnie przy okazji dyskusji nad reformą konstytucji w sejmie II kadencji (choć sformułowano ją i dyskutowano już u progu niepodległości). Warto omówić ją nieco dokładniej, bowiem rzucić może to ciekawe światło na taktykę i dorobek programowy PPS.

Socjaliści postrzegali nowoczesne masowe partie polityczne jako wyraz zorganizowanych dążeń poszczególnych klas. Jak pisał H. Diamand: „Jednolitego społeczeństwa świat cywilizowany nie zna, gdyż istota teraźniejszego społecznego ustroju wymaga podziału każdego społeczeństwa na grupy wspólnych interesów, a ugrupowania takie zorganizowane stanowią partie"32. Również samych siebie traktowali socjaliści w ten sposób, widząc w PPS rzeczniczkę „obiektywnych” in-

29 Zob. Ruch w interesie, Naprzód, 24.01.1929, s .1; F., Sejm na urlopie - parlament przy pracy, Naprzód, 27.07.1929, s. 1.

${ }^{30}$ J.M.B. [J.M. Borski], Lekcja pogladowa, Robotnik, 16.03.1929, s. 1.

31 Zob. np. W.J., Na drogach rozstroju. Niebezpieczeństwa dyktatury, Robotnik, 10.11.1930, s. 2.

${ }^{32}$ H. Diamand, Bezpartyjność a demokracja, Robotnik, 12.06.1929, s. 3; zob. także M. Niedziałkowski, Pogromca „partyjnictwa”, Robotnik, 23.07.1929, s. 1. 
teresów proletariatu, o czym wprost pisał jeden z publicystów „Naprzodu”, stwierdzając, że PPS jest „przedstawicielką, odbiciem i wyrazem” polskiej klasy robotniczej $^{33}$. O ile więc robotnicy, a nawet szerzej, klasy pracujące, uświadomiłyby sobie swój obiektywny interes, wynikający z ich ulokowania w kapitalistycznym systemie produkcji, o tyle można było liczyć, że będą popierać socjalistów i proponowany przez nich program. Oczywiście, socjaliści zdawali sobie sprawę, że będzie to wymagało czasu, niemniej przekonani byli, że przemiana ta dokonuje się w sposób naturalny i wraz z rozwojem procesu dziejowego rosło będzie polityczne uświadomienie klas pracujących, gwarantując w przyszłości wyborcze tryumfy PPS i bratnich partii w innych państwach.

Równolegle z uznaniem, że poszczególne partie polityczne reprezentują bezpośrednio interesy określonych klas i warstw społecznych, socjaliści przyjmowali również założenie, że wyniki wyborów powszechnych są możliwie najwierniejszym odbiciem politycznych sympatii społeczeństwa. W tym sensie miał być to najczulszy barometr, służący pomiarowi układu sił klasowych, a wybrany w pięcioprzymiotnikowych wyborach parlament postrzegali jako arenę, na której toczyć miały się konflikty i spory stanowiące wierne odbicie walk toczonych w obrębie całego społeczeństwa ${ }^{34}$. Twierdził tak choćby publicysta lwowskiego „Dziennika Ludowego”, oceniający, że w warunkach demokracji parlamentarnej każdorazowa zmiana gabinetu dokonuje się w efekcie „przegrupowania sił w społeczeństwie”, zaś sam parlament „złożony z przedstawicieli poszczególnych partii, reprezentujących odnośne ugrupowania społeczne, jest możliwie dokładnym zobrazowaniem układu sił społecznych"35.

Uznanie tożsamości dążeń poszczególnych partii politycznych i interesów klas oraz warstw stanowiących ich podstawową bazę społeczną, w połączeniu z tezą o rzekomym „odbijaniu” układu sił i konfliktów klasowych przez parlament wybrany w pięcioprzymiotnikowych wyborach, pozwalało socjalistom na "klasowe” uzasadnienie swego poparcia dla demokracji parlamentarnej. Zdaniem czołowych publicystów PPS, był to system, który umożliwiał poszczególnym klasom i warstwom uzyskanie wpływu na państwo proporcjonalnego do poziomu ich liczebności i politycznego uświadomienia. M. Niedziałkowski w książce Demokracja parlamentarna $w$ Polsce przekonywał, że jedynie system demokracji parlamentarnej opartej na pięcioprzymiotnikowym prawie do głosowania daje „ścisłość możliwie dokładną" w odbijaniu przez parlament przebiegu konfliktów klasowych w ło-

33 Niebezpieczna gra, Naprzód, 16.06.1929, s. 1.

34 Zob. M. Śliwa, Myśl polityczna..., s. 109-111.

35 Istotne oblicze demokracji (I), Dziennik Ludowy, 27.02.1929, s. 2; Istotne oblicze demokracji (II), Dziennik Ludowy, 28.02.1929, s. 2. 
nie społeczeństwa ${ }^{36}$. Skoro zaś podstawowa zasada geometrii podziałów klasowych w kapitalizmie głosi, że wyzyskiwanych jest zawsze znacznie więcej niż wyzyskiwaczy, a proces politycznego uświadomienia w sposób naturalny postępuje naprzód, to przyszły tryumf socjalizmu wydawać mógł się czymś nieuchronnym, jednocześnie zaś możliwym właśnie na drodze zdobywania coraz większego wpływu na państwo za pomocą parlamentu, nie zaś w efekcie krwawej, długotrwałej walki rewolucyjnej obliczonej na zniszczenie istniejącego porządku i godzącej w państwowe instytucje.

\section{Państwo a walka klas}

Zauważyć należy, że problem państwa, jego funkcji i stosunku jaki powinien wobec niego przyjąć proletariat, stanowił jeden z centralnych punktów dyskusji programowych toczonych w ruchu robotniczym właściwie od jego zarania. Międzywojenny ruch socjalistyczny w swym stosunku do państwa znalazł się niejako, jak ujął to Roman Bäcker, „między Marksem a Jellinkiem” ${ }^{37}$. Z jednej strony bowiem, socjaliści za swą najważniejszą teoretyczną inspirację uważali spuściznę Marksa oraz Engelsa, z wpisaną w nią radykalną krytyką państwa jako instytucji ucisku klasowego, co najlepiej wyrażała formuła z Manifestu komunistycznego, określająca władzę nowoczesnych państw mianem „komitetów zarządzających wspólnymi interesami burżuazji” ${ }^{38}$. Z drugiej jednak strony, postępujący od końca XIX w. proces integracji europejskich partii socjalistycznych $\mathrm{z}$ istniejącym systemem politycznym i gospodarczym, przyspieszony jeszcze pod wpływem fali demokratyzacji, która przelała się przez Stary Kontynent po zakończeniu I wojny światowej, zmuszał do porzucenia tak bezkompromisowego stanowiska i do rewizji stosunku względem instytucji państwa w epoce kapitalizmu.

Szczególną popularność w europejskim ruchu socjalistycznym zdobyły sobie dwie zbliżone do siebie, sformułowane po zakończeniu wojny, teorie wyjaśniające stosunek socjalistów do państwa. Autorem pierwszej z nich był Karol Kautsky, który przekonywał, że wraz z zakończeniem wojny i powszechną demokratyzacją ustrojów politycznych, Europa weszła w „okres przejściowy”, dzielący kapitalizm od, nadchodzącej powoli, epoki socjalistycznej. W „okresie przejściowym”, jak dowodził Kautsky, nie można już było sprawować rządów bez udziału proletariatu,

\footnotetext{
${ }^{36}$ M. Niedziałkowski, Demokracja parlamentarna..., s. 69.

37 R. Bäcker, Problematyka państwa w polskiej myśli socjalistycznej lat 1918-1948, Toruń 1994, s. $7-15$.

${ }^{38}$ K. Marks, F. Engels, Dzieła, t. 4, Warszawa 1962, s. 516.
} 
ale równocześnie samodzielne objęcie przez ruch robotniczy władzy byłoby jeszcze przedwczesne. Innymi słowy, socjaliści nie powinni cofać się przed udziałem w sprawowaniu władzy (np. poprzez uczestnictwo w koalicjach rządowych), dążąc do wykorzystania jej dla przeprowadzenia progresywnych reform społecznych, tworzących zalążki przyszłego społeczeństwa socjalistycznego ${ }^{39}$.

W podobnym duchu prowadził swoje rozważania Otto Bauer, który dowodził, że nowoczesne państwo demokratyczne, rządzone przez wyłonioną w równych i powszechnych wyborach większość, przestało być już narzędziem wykorzystywanym bezceremonialnie przez klasy posiadające $\mathrm{w}$ celu podtrzymania swego panowania. Dla Bauera, nowoczesne państwo demokratyczne (nazywane przez niego czasem „republiką ludową”) stało się przestrzenią, w której toczy się walka, w rezultacie której klasowe zabarwienie rządów przechyla się raz w jedną, raz $\mathrm{w}$ drugą stronę, godząc jednocześnie w partykularne interesy zantagonizowanych klas społecznych. Wobec względnej równowagi sił klasowych, w warunkach powojennej demokracji niemożliwym było, zdaniem Bauera, otwarte wykorzystanie aparatu państwowego do brutalnego zwalczania klasowego przeciwnika, gdyż prowadzić mogłoby to do destrukcji istniejącego porządku, czego nie chciała ryzykować żadna z liczących się w tym starciu stron. W tym sensie państwo, choć uwikłane w przenikającą nowoczesne społeczeństwa, walkę klasową, stawało się instytucją w pewnym przynajmniej stopniu „ponadklasową"40.

Do wywodów Bauera oraz Kautsky’ego polscy socjaliści odwoływali się bardzo chętnie, również podczas trwania debaty konstytucyjnej w sejmie II kadencji. PPS odrzucała jednostronnie klasową definicję państwa, jednocześnie jednak starano się unikać definiowania państwa w neutralnych kategoriach prawniczych, tak, jak proponował to choćby wspomniany już Georg Jellinek. Walka klas pozostawała

39 Zob. M. Waldenberg, Wzlot i upadek Karola Kautsky'ego. Studium z historii myśli społecznej i politycznej, t. 2, Kraków 1972, s. 426-444; M. Salvadori, Karl Kautsky and the Socialist Revolution 1880-1938, London-New York 1990, s. 325-329.

40 Badaczka myśli politycznej O. Bauera, Ewa Czerwińska pisze: „Otóż Bauer był przekonany, że w warunkach równowagi sił klasowych wykształciła się „ultrademokratyczna” forma państwa (republika ludowa). Jej istota polegać miała na skorygowanej przez demokrację funkcjonalnej wersji systemu parlamentarnego. [...] charakterystyka danej przez Bauera formy ustrojowej zawierała się w poddaniu władzy wykonawczej kontroli parlamentarnej wzmocnionej kontrolą organizacji społecznych. Bauer zakładał, że w wyniku ukonstytuowania się silnych pozaparlamentarnych grup nacisku, głównie pracowniczych, rząd będzie musiał oprzeć się nie tylko na wybranym demokratycznie na okres legislacyjny parlamencie, lecz uzyskać dla swych działań zgodę autonomicznych organizacji obywatelskich. Ze zmianą formy sprawowania władzy Bauer wiązał zmianę funkcji państwa: miało się ono przekształcić ze strażnika kapitalistycznego porządku ekonomicznego i społecznego w pośrednika między partykularnymi interesami grup społecznych”, E. Czerwińska, Studium myśli społeczno-politycznej Otto Bauera (1881-1938), t. 2: Utracona demokracja, Poznań 1998, s. 95-100. 
wciąż dla socjalistów podstawowym faktem społecznym i punktem wyjścia podejmowanych rozważań. Rolę państwa w toczącym się konflikcie klasowym, publicyści i przywódcy PPS skłonni byli ujmować w dwojaki sposób. Po pierwsze, państwo jawiło się im jako siła, mogąca wyznaczać instytucjonalne warunki, gdzie toczył się konflikt klasowy, przyczyniając się do zwiększenia szans którejś z uczestniczących w nim stron. Na przykład, poprzez wprowadzenie odpowiedniego ustawodawstwa, państwo mogło wzmocnić pozycję robotników czy reprezentujących ich związków zawodowych w walce z kapitalistą, ale mogło też ograniczyć prawo robotników do zrzeszania się i pozbawić działaczy związkowych prawnej ochrony.

Jednocześnie, socjaliści zauważali - idąc tutaj też za intuicją O. Bauera - że instytucje nowoczesnego państwa demokratycznego, w przeciwieństwie do swoich dziewiętnastowiecznych poprzedników, stały się kolejną przestrzenią (być może najważniejszą), w której toczy się konflikt klasowy, a celem ruchu robotniczego powinno stać się zdobycie możliwie największego „wpływu na państwo”. Tym samym, nowoczesne państwo, mimo trwania wciąż systemu kapitalistycznego, nie tylko przestało być przez socjalistów traktowane jako narzędzie opresji i ucisku, ale wręcz zaczęło być postrzegane jako potencjalnie najpotężniejsza dźwignia emancypacji klas pracujących ${ }^{41}$. Innymi słowy, socjalizm nie miał być budowany „poza” państwem czy też „po” państwie (tj. po zniszczeniu instytucji państwa epoki kapitalistycznej) lecz właśnie „przez” państwo, nawet jeżeli funkcjonowało ono na razie w ramach systemu kapitalistycznego.

W tej sytuacji nie powinna zaskakiwać, wyraźnie obecna w retoryce socjalistów w 1.20 ., a także w toku debaty konstytucyjnej, toczącej się na forum sejmu II kadencji, wyraźna afirmacja instytucji państwa ${ }^{42}$. Oczywiście, ogromną rolę odgrywały tutaj patriotyczne i niepodległościowe tradycje PPS, niemniej warto podkreślić, że owa afirmacja posiadała również swoje źródło w teoretycznych dociekaniach socjalistów, w których za punkt wyjścia brany był fakt klasowego podziału społeczeństwa i wynikające z tego antagonizmy. Na poziomie politycznej agitacji, afirmacja ta przyjmowała formy podobne choćby do argumentacji obecnej w charakterystycznym artykule Jana Stańczyka, w którym przekonywał on czytel-

${ }^{41}$ Por. M. Śliwa, Myśl polityczna..., s. 96.

${ }^{42}$ Dało to o sobie wyraźnie znać podczas jednego z posiedzeń Komisji Konstytucyjnej, kiedy H. Liberman posunął się aż do kontrowersyjnej opinii, jakoby socjaliści uważali państwo za instytucję stworzoną dla korzyści całego społeczeństwa. „My uważamy - mówił Liberman - że państwo zostało stworzone dla dobra ludzi, że ludzie się zawiązali w społeczeństwo dla dobra ludzi, a organem, którym się posługują ludzie w społeczeństwie, jest państwo”. Sprowokowało to Wacława Makowskiego do kąśliwej, ale i nie pozbawionej podstaw uwagi że słowa Libermana są ,trochę rewelacyjne z punktu widzenia socjalistycznego", zob. Prace Komisji Konstytucyjnej..., s. 247. 
ników „Robotnika”, że zdobycie przez proletariat wpływu na instytucje państwowe (za pośrednictwem socjalistycznej reprezentacji parlamentarnej) wprost przekłada się na kierunki polityki gospodarczej rządu i decyzje podejmowane przez organa państwowe podczas postępowania arbitrażowego w razie konfliktów między kapitałem i światem pracy ${ }^{43}$.

\section{Zradykalizować demokrację}

Nadzieja, że państwo uczynić można główną dźwignią emancypacji klas pracujących, legła również u podstaw, złożonego 4 marca 1929 projektu konstytucji, który sygnowali, obok posłów PPS, również członkowie klubów sejmowych PSL "Wyzwolenie” oraz Stronnictwa Chłopskiego ${ }^{44}$. Najważniejsze postulaty socjalistów stanowiły, poza kilkoma wyjątkami, w zasadzie powtórzenie rozwiązań zaproponowanych już podczas debaty konstytucyjnej w Sejmie Ustawodawczym. Chcąc zradykalizować polską demokrację, posłowie PPS żądali zniesienia senatu, utworzenia Izby Pracy, ludowej inicjatywy ustawodawczej oraz otwarcia przez ustawę zasadniczą możliwości ingerencji państwa w stosunki własności, tak, aby możliwe było stopniowe uspołecznienie środków produkcji. Likwidacja senatu usunąć miała pewne „zniekształcenia” w parlamentarnym odbiciu układu sił klasowych, wynikłe z podwyższonego cenzusu wieku i powszechnego przekonania o elitarnym oraz konserwatywnym charakterze drugiej izby. Powołanie do życia Izby Pracy obliczone było natomiast na instytucjonalne wzmocnienie pozycji świata pracy w konflikcie klasowym, stanowiąc bezpośredni wyraz nadziei socjalistów, że możliwe jest wykorzystanie instytucji państwowych w walce przeciwko kapitalistom. Również dążenie do konstytucyjnego uregulowania kwestii własności traktować należy jako wyraz nadziei, że dzięki przyszłym politycznym sukcesom ruchu robotniczego, możliwym będzie wykorzystanie istniejącego aparatu państwowego do przeprowadzenia uspołecznienia środków produkcji.

Warto jednocześnie dodać, że oprócz tych zupełnie zasadniczych postulatów ustrojowych, projekt rewizji konstytucji złożony przez parlamentarną lewicę, z PPS na czele, zawierał również szereg bardziej szczegółowych zapisów, będących próbą skorygowania niedoskonałości konstytucji marcowej, które objawiły się w toku jej

${ }^{43}$ J. Stańczyk, Wptyw politycznej organizacji klasy robotniczej na akcje zawodowe, Robotnik, 9.01.1929, s. 1.

${ }^{44}$ Zestawienie wszystkich złożonych w sejmie II kadencji projektów nowelizacji konstytucji zawierał załącznik do druku sejmowego nr 777 , przedrukowany w cytowanym już tomie opracowanym przez M. Wojtackiego, zob. Prace Komisji Konstytucyjnej..., s. 369-426. 
funkcjonowania, zarówno przed, jak i po zamachu majowym ${ }^{45}$. Postulowano m.in. ograniczenie samowoli prezydenta w dziedzinie zwoływania, otwierania i odraczania sesji sejmowych, określenie terminu ogłaszania aktów prawnych w „Dzienniku Ustaw", konstytucyjny zakaz udziału urzędników w kampanii wyborczej, stworzenie Komisji Kodyfikacyjnej przy sejmie oraz odsunięcie o osiem dni od momentu złożenia, terminu głosowania nad wnioskiem o wotum nieufności dla rządu. Propozycje te trudno uznać, za wyrastające z ówczesnych założeń teoretycznych polskiego ruchu socjalistycznego. Była to raczej, pragmatyczna próba wyeliminowania albo ograniczenia najbardziej rażących niedoskonałości obowiązującej ustawy zasadniczej, wynikłych nie tyle z jakiejś określonej wizji ustrojowej, ale będących efektem dwuznacznej albo zbyt ogólnikowej redakcji poszczególnych artykułów.

\section{Debata konstytucyjna i zmierzch optymistycznej wizji dziejów}

Przy pierwszym oglądzie, przebieg debaty konstytucyjnej w sejmie II kadencji budzić może pewne zdziwienie. Chociaż problem "naprawy ustroju” od wielu już lat stanowił jeden z najchętniej podejmowanych tematów debaty publicznej, a przywódcy niemal wszystkich ugrupowań zgadzali się, że ustawa zasadnicza wymaga korekty, to prace nad tym zagadnieniem toczyły się w sejmie dość niemrawo, nawet pomimo uproszczonej procedury nowelizacyjnej przewidzianej przez art. 125 obowiązującej ustawy zasadniczej. Przy ówczesnym układzie sił w izbie i wobec rosnącej temperatury konfliktu między parlamentarną opozycja a rządem, wiadomym było, że wypracowanie kompromisu i zgodna z obowiązującym prawem nowelizacja konstytucji, będzie zadaniem niezwykle trudnym, a może wręcz niemożliwym.

Debatę konstytucyjną jej uczestnicy w dużej mierze wykorzystali wobec tego w celu bieżącej agitacji i walki politycznej z przeciwnikami. Podobnie było również z socjalistami, którzy stosunkowo mało uwagi poświęcali własnemu projektowi reformy konstytucji, a skupili się na krytyce rozwiązań proponowanych przez BBWR, chcąc przy tej okazji kompromitować obóz pomajowy w oczach opinii publicznej. Warto przy tym zauważyć, że socjaliści w dyskusji nad reformą ustrojową ograniczyli się w zasadzie do powtórzenia (choć często w bardziej rozbudowanej formie) argumentów, którymi posługiwali się od zarania Drugiej Rzeczypospolitej. Debata konstytucyjna nie przyniosła w ich wypadku żadnych poważniejszych teoretycznych nowinek czy prób poważniejszej rewizji dotychczas głoszo-

45 Ibidem. 
nych poglądów. Mimo to, jak starałem się pokazać w niniejszym artykule, publicystyka socjalistów przypadająca na ten okres, warta jest szczególnego zainteresowania, bowiem specyfika debaty ustrojowej wymusiła na socjalistach bardziej systematyczną i uporządkowaną prezentację własnych poglądów na temat państwa, dynamiki przemian i walk społecznych oraz trajektorii procesu dziejowego w ogóle. Milcząco często przyjmowane założenia i ważkie tezy, rozproszone wcześniej zwykle w różnych tekstach agitacyjnych, uchwałach władz partyjnych czy doraźnej publicystyce, wypowiadane były przy okazji dyskusji nad reformą konstytucji wprost i z dużą częstotliwością.

Wydaje się również, że dyskusja ta w pewnym sensie wieńczy i podsumowuje pierwsze dziesięciolecie rozwoju polskiej myśli socjalistycznej w niepodległym państwie. Socjaliści europejscy w 1. 20. hołdowali swoiście optymistycznej historiozofii, wierząc, że dokonujące się po I wojnie światowej przemiany w sposób naturalny wiodą do ustanowienia społeczeństwa socjalistycznego ${ }^{46}$. Postępująca demokratyzacja, wzrost siły ruchu robotniczego w poszczególnych państwach europejskich, czy wreszcie pewna stabilizacja gospodarki kapitalistycznej, dająca nadzieję, że proces uspołecznienia dokonywał będzie się stopniowo i w warunkach gospodarczej prosperity - wszystko to utwierdzało socjalistów w wierze, że historia jest na właściwym torze, a ich pełna wstrzemięźliwości i umiarkowania polityka stanowi najlepszą rękojmię ostatecznego sukcesu. Powszechnemu wówczas wśród pepesowców przekonaniu, że proces dziejowy w naturalny sposób prowadzi do socjalizmu, w doskonały sposób dał wyraz jeden z publicystów prowincjonalnego tygodnika "Głos Zagłębia”, pisząc: „Socjalizm idzie bo nadejść musi. Zaiste dzisiaj dopiero widzimy jak daleko sięgali wzrokiem w przyszłość Marks i jego współpracownicy. Nowoczesne zdobycze nauki pchają produkcję do scentralizowania się, wszędzie, nawet w Polsce widzimy ten pęd do tworzenia karteli, trustów czy syndykatów. Kapitał się koncentruje. Zwiększa się ilość proletariatu a zmniejsza się ilość drobnomieszczaństwa. Drobnomieszczaństwo przechodzi do kategorii pracowników umysłowych, ale również łączy się z proletariatem fizycznym. Socjalizm staje się koniecznością i wsi”" ${ }^{3}$.

Przekonanie o tym, że dokonuje się powolny, ewolucyjny proces przerastania kapitalizmu w socjalizm utwierdzało przywódców i publicystów PPS w przekonaniu, że zasadniczą treść walki klasowej stanowić powinna rozbudowa organizacji robotniczych i długofalowa praca na rzecz politycznego uświadomienia prole-

${ }^{46}$ Zob. D.S. White, Reconsidering European Socialism in the 1920s, Journal of Contemporary History 1981, Vol. 16, No. 2 , s. 251-252.

47 Socjalista, Socjalizm jako wyższa forma gospodarcza, Głos Zagłębia 1929, nr 19, s. 2. 
tariatu. Państwo zajęło wówczas centralną pozycję w filozofii politycznej polskich socjalistów. Jawiło się przy tym raczej jako sojusznik klasy robotniczej i narzędzie przyszłej emancypacji, nie zaś - jak w dziewiętnastowiecznej tradycji marksistowskiej - jako instytucja opresji i oręż w rękach kapitalistów. Wizją tą zachwiały dopiero wydarzenia przełomu lat 20. i 30. Klęska Centrolewu i umocnienie pomajowej dyktatury, a także kryzys gospodarczy, podważający wiarę w możliwość stabilizacji kapitalizmu oraz tryumfalny pochód ruchów faszystowskich i autorytarnych przez Stary Kontynent postawiły pod znakiem zapytania historiozoficzny optymizm socjalistów. Kolejne lata okazały się dla nich czasem ideowych poszukiwań, niejednokrotnie poddających w wątpliwość albo wprost odrzucających te założenia teoretyczne, którym wyraz dali podczas debaty nad reformą konstytucji w sejmie II kadencji. 